\title{
Mucopolysaccharidoses in northern Brazil: Targeted mutation screening and urinary glycosaminoglycan excretion in patients undergoing enzyme replacement therapy
}

\author{
Gustavo M. Viana ${ }^{1}$, Nathália O. de Lima ${ }^{1}$, Rosely Cavaleiro ${ }^{1}$, Erik Alves ${ }^{1}$, Isabel C.N. Souza ${ }^{2}$, \\ Raimunda Feio $^{2}$, Sandra Leistner-Segal ${ }^{4}$, Ida Schwartz ${ }^{3,4}$, Roberto Giugliani ${ }^{3,4}$ and Luiz C. Santana da Silva ${ }^{1}$ \\ ${ }^{1}$ Laboratório de Erros Inatos do Metabolismo, Instituto de Ciências Biológicas, \\ Universidade Federal do Pará, Belém, PA, Brazil. \\ ${ }^{2}$ Hospital Universitário Bettina Ferro de Souza, Universidade Federal do Pará, Belém, PA, Brazil. \\ ${ }^{3}$ Departamento de Genética, Universidade Federal do Rio Grande do Sul, Porto Alegre, RS, Brazil. \\ ${ }^{4}$ Serviço de Genética Médica, Hospital de Clínicas de Porto Alegre, Porto Alegre, RS, Brazil.
}

\begin{abstract}
Mucopolysaccharidoses (MPS) are rare lysosomal disorders caused by the deficiency of specific lysosomal enzymes responsible for glycosaminoglycan (GAG) degradation. Enzyme Replacement Therapy (ERT) has been shown to reduce accumulation and urinary excretion of GAG, and to improve some of the patients' clinical signs. We studied biochemical and molecular characteristics of nine MPS patients (two MPS I, four MPS II and three MPS VI) undergoing ERT in northern Brazil. The responsiveness of ERT was evaluated through urinary GAG excretion measurements. Patients were screened for eight common MPS mutations, using PCR, restriction enzyme tests and direct sequencing. Two MPS I patients had the previously reported mutation p.P533R. In the MPS II patients, mutation analysis identified the mutation p.R468W, and in the MPS VI patients, polymorphisms p.V358M and p.V376M were also found. After 48 weeks of ERT, biochemical analysis showed a significantly decreased total urinary GAG excretion in patients with MPS I $(p<0.01)$ and MPS VI $(p<0.01)$. Our findings demonstrate the effect of ERT on urinary GAG excretion and suggest the adoption of a screening strategy for genotyping MPS patients living far from the main reference centers.
\end{abstract}

Key words: mucopolysaccharidosis, enzyme replacement therapy, mutations, glycosaminoglycans.

Received: July 8, 2010; Accepted: March 23, 2011.

The mucopolysaccharidoses (MPS) are a rare group of lysosomal storage diseases (LSD) with an autosomal recessive inheritance pattern (with the exception of MPS II, which is an X-linked) and characterized by the accumulation of glycosaminoglycans (GAG) in the lysosomes. This accumulation occurs due to low or absent lysosomal enzyme activity, essential to the GAG catabolism, and results in systemic impairment of organs and tissues (Neufeld and Muenzer, 2001).

With an incidence ranging from 1:10000 to 1:25000 newborns worldwide, MPS appear to be among the most frequent LSDs. MPS I and II were found to be the most frequent, while MPS VI is reported to have a lower incidence (Solyom, 1996; Meikle et al., 1999). The MPS Brazil Network, an initiative created to improve the diagnosis and management of these diseases in Brazil between 2004 and

Send correspondence to Luiz Carlos Santana da Silva. Laboratório de Erros Inatos do Metabolismo, Instituto de Ciências Biológicas, Universidade Federal do Pará, R. Augusto Corrêa n. 01, 66075-110 Belém, PA, Brazil. E-mail: Icss@ufpa.br.
2006, identified 161 MPS patients, among which MPS II showed the highest incidence $(\mathrm{n}=82)$ and MPS VII the lowest $(\mathrm{n}=4)$. Castro et al. (2007) reported a high incidence of MPS II and VI in patients from northern Brazil, followed by MPS I.

So far, eleven different subtypes of MPS have been identified (Neufeld and Muenzer, 2001). Patients with MPS present similar chronic and progressive clinical features, but symptoms may vary depending on the type. Organomegaly, dysostosis multiplex, hepatosplenomegaly, joint contractures and characteristic facial changes are common symptoms described in these patients. Other systemic impairments may also occur, such as hearing deficiencies, cardiorespiratory disorders, low articular mobility and loss of visual acuity (Neufeld and Muenzer, 2001; Muenzer, 2004).

Enzyme Replacement Therapy (ERT) is considered an efficient therapeutic method in MPS treatment. It is based on the periodic replacement of the defective enzyme, leading to higher GAG degradation in tissues and organs, 
promoting a significant improvement in some clinical features. However, the influence of ERT on other pathological manifestations, like progressive skeletal disease, arthropathy, central nervous system dysfunction, cardiac involvement and visual impairment, is still not well understood (Miebach, 2005; Arora et al., 2007; El Dib and Pastores, 2007; Pitz et al., 2009).

Previous studies have proposed urinary GAG dosage as a biochemical parameter for evaluating the efficacy of ERT protocols. After some months of treatment, the majority of patients undergoing ERT showed an improvement of many clinical symptoms, which was correlated with a significant reduction in urinary GAG excretion (Harmatz et al., 2005, 2008; Arora et al., 2007; Sifuentes et al., 2007; Muenzer et al., 2009).

The isolation and characterization of genes involved in the depletion of GAG catabolism enzymes led to the identification of many disease-causing mutations related to MPS. Despite the great variability presented by MPS patients, some mutations were reported to be frequent in some specific populations (Matte et al., 2000; Petry et al., 2005; Alves et al., 2006; Mangas et al., 2008).

The aims of this study were to investigate common MPS mutations in patients from northern Brazil and to analyze the efficacy of ERT by means of urinary GAG measurements.

We studied nine patients with MPS from a region in northern Brazil (state of Pará), two of which with MPS I, four with MPS II, and three with MPS VI. The diagnoses, made by the Medical Genetics Service (SGM) of the Hospital de Clínicas de Porto Alegre, were based on abnormal urinary GAG excretion (before starting ERT) and leukocyte enzyme activity. All patients had clinical manifestations of the disease, and the diagnosis was confirmed by a leukocyte enzyme activity $<20 \%$ of the normal range established by our laboratory. Some clinical parameters, such as age, consanguinity, height, corneal opacification and cardiac dysfunctions, were analyzed in each patient, for phenotype determination (Table 1). This study was reviewed and approved by the Human Research Ethics Committee of the Instituto de Ciências da Saúde, Universidade Federal do Pará (protocol no. \#172/2008 - November 11 $1^{\text {th }}$, 2008).

The recombinant enzymes laronidase (Aldurazyme ${ }^{\circledR}$, recombinant human $\alpha$-L-iduronidase; BioMarin Pharmaceutical Inc., Novato, CA, USA; Genzyme Corporation, Cambridge, MA, USA) and galsulfase (Naglazyme ${ }^{\circledR}$, recombinant human ASB; BioMarin Pharmaceutical Inc., Novato, CA, USA) were administered intravenously once a week for 48 weeks, at a dosage of $1 \mathrm{mg} / \mathrm{kg}$ bodyweight for MPS I, and $0.58 \mathrm{mg} / \mathrm{kg}$ bodyweight for MPS VI, respectively. For MPS II ERT, idursulfase (Elaprase ${ }^{\circledR}$, Shire HGT) at a dosage of $0.50 \mathrm{mg} / \mathrm{kg}$ was intravenously administered.

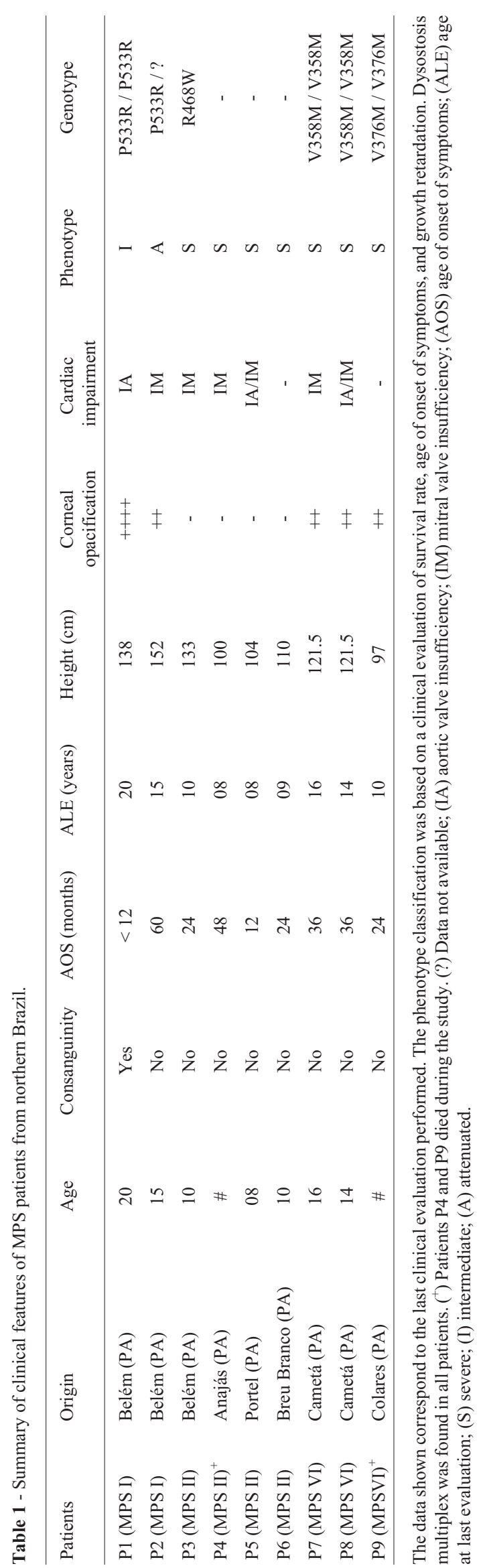


Genomic DNA was extracted from peripheral blood using the phenol-chloroform technique (Sambrook and Russel, 2001). PCR reactions and restriction enzyme tests were designed to screen for eight known MPS mutations: p.Q70X, p.W402X and p.P533R (IDUA gene, MPS I); p.R468W, p.R468Q and p.P467L (IDS gene, MPS II); p.R315Q and 1533del23 (ARSB gene, MPS VI), with the exception of exons 3 and 9 (IDS gene), which were directly sequenced after amplification.

PCR was performed in a total reaction volume of $50 \mu \mathrm{L}$, containing $100 \mathrm{ng}$ of DNA, $2 \mathrm{mmol} / \mathrm{L}$ of dNTP, $1 \mathrm{x}$ PCR buffer (10 mmol/L TRIS-HCl, pH 8.3; $50 \mathrm{mmol} / \mathrm{L}$ $\mathrm{KCl}$ ), 20 pmol of each primer (forward and reverse), $1.5 \mathrm{mmol} / \mathrm{L} \mathrm{MgCl}_{2}$, and $1 \mathrm{U}$ of Taq DNA polymerase (Invitrogen). Cycling conditions were typically $94^{\circ} \mathrm{C}$ for $5 \mathrm{~min}$, followed by 35 cycles of $1 \mathrm{~min}$ at $94^{\circ} \mathrm{C}, 1 \mathrm{~min}$ at $55-66^{\circ} \mathrm{C}$, $1 \mathrm{~min}$ at $72{ }^{\circ} \mathrm{C}$, and a final extension at $72^{\circ} \mathrm{C}$ for $10 \mathrm{~min}$. All amplifications were carried out in an MG96+ Peltier-Based Thermal Cycler (Biosystems). For control, PCR reactions with no DNA (blank) were used during each reaction. The amplified fragments were visualized in $2 \%$ agarose gel containing ethidium bromide.

After amplification, the PCR products were subjected to direct sequencing for mutation and/or polymorphism detection, using the BigDye 3.1 Terminator Cycle Sequencing kit (Applied Biosystems, Foster City, CA), in an ABI PRISM 377 DNA Sequencer (Applied Biosystems). Some sequence changes were confirmed by digestion with specific restriction enzymes. Targeted mutations, primer se- quences, fragment lengths and restriction enzymes are presented in Table 2.

The total GAG concentration in urine samples of MPS patients undergoing ERT was determined by a method based on spectrophotometric detection of metachromatic changes to the 1,9-dimethylmethylene blue (DMB) dye, resulting from GAG binding (Whitley et al. 1989). Urinary creatinine concentrations were also measured separately in order to normalize urinary GAG concentrations (mg GAG/mmol creatinine). Condroitin sulfate was used as standard control in DMB binding measurements.

For the urinary GAG concentrations, all descriptive statistics, including means, standard deviations (SD), and percent change over time were calculated using the Biostat 5.0 Software. Changes in parameters between baseline (before starting treatment) and after 48 weeks of ERT were evaluated using Student's $t$ test $(\mathrm{p}=0.05)$.

After amplification and direct sequencing of the amplified fragments, two previously described mutations were identified among the nine studied MPS patients: mutation p.P533R, common in patients with MPS I, was detected in patient P1 (homozygous) and patient P2 (heterozygous); another mutation, frequent in MPS II patients (p.R468W), was identified only in patient P3. In addition, two common polymorphisms (p.V358M and p.V376M) were found in MPS VI patients.

A significant decrease in relative urinary GAG concentration was observed in all patients with MPS I undergo-

Table 2 - Sequence and orientation of primer pairs used for amplification of MPS gene fragments.

\begin{tabular}{|c|c|c|c|c|c|}
\hline MPS Subtype & Mutation & Primer $\left(5^{\prime} \rightarrow 3^{\prime}\right)$ & Product size (bp) & Restriction enzyme & Product size (bp) \\
\hline MPS I & $\begin{array}{l}\text { p.Q70X } \\
\text { (exon 2) }\end{array}$ & $\begin{array}{l}\text { GGCTTGAACGTGTGTGTCAG (F) } \\
\text { TCCCATCTGTGCCTCTGTAA (R) }\end{array}$ & 274 & -Sau96I & $\begin{array}{l}\mathrm{N}: 122+95+57 \\
\mathrm{M}: 179+95\end{array}$ \\
\hline MPS I & $\begin{array}{l}\text { p.W402X } \\
\text { (exon 9) }\end{array}$ & $\begin{array}{l}\text { CTGGGGACTCCTTCACCAAG (F) } \\
\text { CAGAGACCTCCCTGGAACC (R) }\end{array}$ & 354 & $+\mathrm{BfaI}$ & $\begin{array}{c}\mathrm{N}: 354 \\
\mathrm{M}: 227+127\end{array}$ \\
\hline MPSI & $\begin{array}{l}\text { p.P533R } \\
\text { (exon 11) }\end{array}$ & $\begin{array}{l}\text { GTGTGGGTGGGAGGTGGA (F) } \\
\text { TTAGGGGACTGCCACTTGC (R) }\end{array}$ & 250 & - & - \\
\hline MPS II & Exon 3 & $\begin{array}{l}\text { AAGCATCTGCTGGTTTCAGG (F) } \\
\text { CAGACTCTGGACATGGAGCA (R) }\end{array}$ & 423 & - & - \\
\hline MPS II & $\begin{array}{l}\text { p.R468W } \\
\text { (exon } 9 \text { I) }\end{array}$ & $\begin{array}{l}\text { CATATGGAGCCCAGACAGGT (F) } \\
\text { ATGCTGCGTATGGAATAGCC (R) }\end{array}$ & 399 & -MspI & $\begin{array}{l}\mathrm{N}: 316+83 \\
\mathrm{M}: 399\end{array}$ \\
\hline MPS II & $\begin{array}{l}\text { p.R468Q } \\
\text { (exon 9 I) }\end{array}$ & $\begin{array}{l}\text { CATATGGAGCCCAGACAGGT (F) } \\
\text { ATGCTGCGTATGGAATAGCC (R) }\end{array}$ & 399 & -TaqI & $\begin{array}{l}\mathrm{N}: 241+158 \\
\mathrm{M}: 399\end{array}$ \\
\hline MPS II & $\begin{array}{l}\text { p.P467L } \\
\text { (exon 9 I) }\end{array}$ & $\begin{array}{l}\text { CATATGGAGCCCAGACAGGT (F) } \\
\text { ATGCTGCGTATGGAATAGCC (R) }\end{array}$ & 399 & -NciI & $\begin{array}{l}\mathrm{N}: 316+83 \\
\mathrm{M}: 399\end{array}$ \\
\hline MPS II & Exon 9 II & $\begin{array}{l}\text { CCCGTGAACTGATTGCCTAT (F) } \\
\text { ACTAGCCCTCAGGCTGCTTC (R) }\end{array}$ & 400 & - & - \\
\hline MPS VI & $\begin{array}{l}\text { p.R315Q } \\
\text { (exon 5) }\end{array}$ & $\begin{array}{l}\text { TCATCCTCATGCCAAGACCT }(\mathrm{F}) \\
\text { GAAAAAGGGCAGGGTGTAGG (R) }\end{array}$ & 300 & -TaqI & $\begin{array}{l}\mathrm{N}: 179+77+44 \\
\mathrm{M}: 256+44\end{array}$ \\
\hline MPS VI & $\begin{array}{c}1533 \text { del23 } \\
\text { (exon } 8 \text { ) }\end{array}$ & $\begin{array}{l}\text { CCTCTGTGCTTCTCCCTCAG (F) } \\
\text { CTTCCAATTGAAAGGTTTTC (R) }\end{array}$ & 347 & - & - \\
\hline
\end{tabular}

(F) forward; (R) reverse; N: normal; M: mutant; +/- gain or loss of restriction enzyme site, respectively. All primers were designed by our group, using the Primer3 Software (http://www.genome.wi.mit.edi/cgi-bin/primer3_www.cgi). 
ing ERT when compared to baseline (Figure 1). In patient $\mathrm{P} 1$, the initial urinary GAG concentration of $76.38 \mathrm{mg}$ GAG/mmol creatinine (single dosage) decreased to $12.34 \pm 9.35 \mathrm{mg} \mathrm{GAG} / \mathrm{mmol}$ creatinine at week 6 , representing a reduction of approximately $84 \%(\mathrm{p}<0.001)$ in the urinary GAG excretion rate. This reduction became more evident in the subsequent weeks, reaching values of $10.20 \pm 6.89 \mathrm{mg} \mathrm{GAG} / \mathrm{mmol}$ creatinine ( $86 \%$ reduction) during week 12, and this level was maintained until the end of the analyzed period (48 weeks).

Patient P2 (MPS I) also presented a significant reduction in urinary GAG excretion after starting ERT. At baseline, the urinary GAG concentration was $17.27 \mathrm{mg}$ $\mathrm{GAG} / \mathrm{mmol}$ creatinine, and at week 6 this excretion was reduced to $9.17 \pm 4.1$, which corresponds to a $47 \%$ reduction $(\mathrm{p}<0.05)$. However, at week 12 , these values had oscillated, returning to higher levels $(16.4 \pm 7.6 \mathrm{mg} \mathrm{GAG} / \mathrm{mmol}$ creatinine) decreasing again by weeks 18 and 24 (11.1 \pm 7.2 and $4.3 \pm 0.53 \mathrm{mg} \mathrm{GAG} / \mathrm{mmol}$ creatinine, respectively). In this patient $(\mathrm{P} 2)$, the urinary GAG concentrations could not be measured after week 24 , because at that time his treatment was discontinued.

Patient P5 (MPS II) also presented a significant reduction in urinary GAG excretion after starting ERT. At baseline, the urinary concentration was $12.41 \mathrm{mg}$ GAG/mmol creatinine, decreasing to $4.2 \mathrm{mg} \mathrm{GAG} / \mathrm{mmol}$ creatinine by week 5 , a reduction of approximately $66 \%$ (data not shown).

Patients with MPS VI also showed a significant reduction in their urinary GAG excretion during ERT (Figure 2). In patient $P 7$, the mean value of urinary GAG excretion at baseline was $31.9 \mathrm{mg} \mathrm{GAG} / \mathrm{mmol}$ creatinine. After starting ERT, this concentration had decreased to $6.17 \pm 2.79 \mathrm{mg} \mathrm{GAG} / \mathrm{mmol}$ creatinine by week 6 , a reduction of approximately $81 \%(\mathrm{p}<0.01)$. This concentration remained stable until week 36 , when a discrete but not sig-

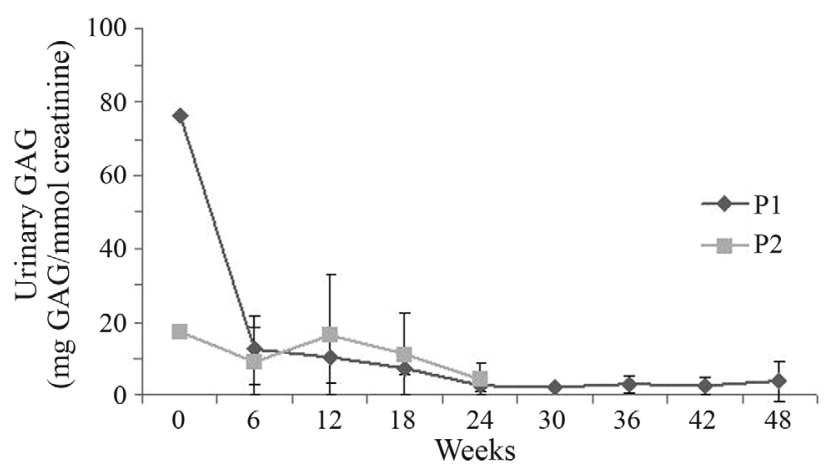

Figure 1 - Urinary GAG excretion in patients with MPS I during ERT. Values represent the 6-week means of GAG excretion for patient P1 (dark line) and patient P2 (gray line). The mean reduction was significant in both patients when compared to GAG concentration at baseline $(\mathrm{p}<0.01)$. Measurements of GAG excretion of patient P2 after week 24 were not possible because his treatment was discontinued. Error bars represent the standard deviation of the measurement in each analyzed week.

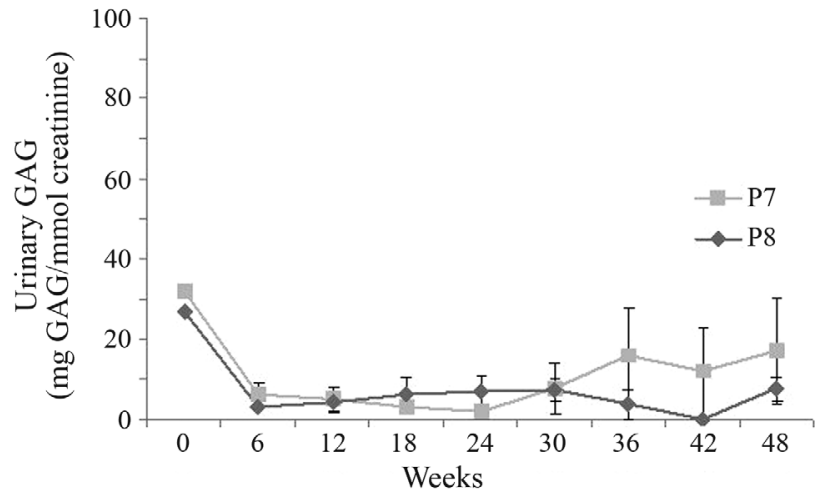

Figure 2 - Urinary GAG excretion in patients with MPS VI during ERT. Values represent the 6-week means of GAG excretion for patient P7 (dark line) and patient P8 (gray line). The mean reduction was significant in both patients when compared to GAG concentration at baseline $(p<0.01)$. Error bars represent the standard deviation of the measurement in each analyzed week.

nificant $(\mathrm{p}>0.05)$ increase was observed compared to baseline. Changes in urinary GAG concentration were also observed in patient $\mathrm{P} 8$, who presented a significant reduction of $88 \%(\mathrm{p}<0.01)$ at week $6(3.16 \pm 0.80 \mathrm{mg} \mathrm{GAG} / \mathrm{mmol}$ creatinine) as compared to baseline (26.92 $\mathrm{mg} \mathrm{GAG} / \mathrm{mmol}$ creatinine).

In this study, we found two targeted mutations: p.P533R in two patients with MPS I, and p.R468W in one patient with MPS II. Moreover, two previously described polymorphisms (p.V358M and p.V376M) were detected in patients with MPS VI. None of the other investigated mutations were found.

Mutation p.P533R, identified in homozygosis in patient $\mathrm{P} 1$ and in heterozygosis in patient $\mathrm{P} 2$, has been previously reported in Brazilian patients by Matte et al. (2003), who described different phenotypes in patients with the same mutation. Previously, Gatti et al. (1997) and Venturi et al. (2002) had also reported variable phenotypes in the presence of the p.P533R mutation in Italian MPS I patients.

Patient P3 (MPS II), who presented the p.R468W mutation, had a phenotype classified as severe, differing from results reported in the literature.

This difficulty in establishing genotype/phenotype correlations may result from some unaccounted factors, such as the rarity of this disease and the inheritance profile of the mutations.

Some studies suggest that certain mutations involving $\mathrm{C}>\mathrm{T}$ or $\mathrm{G}>\mathrm{A}$ transitions in $\mathrm{CpG}$ dinucleotides are due to in situ methylation-deamination processes and, therefore, these regions are considered hotspots for mutation identification. The $\mathrm{p} . \mathrm{R} 468 \mathrm{~W}$ mutation is caused by a $\mathrm{C}>\mathrm{T}$ change in $\mathrm{CpG}$ regions and is, therefore, considered a hotspot. However, its role in phenotype determination is not yet well understood, due to the high heterogeneity of this gene.

According to Froissart et al. (2007), seven out of eight patients with attenuated phenotypes carried a missense mutation, including p.R468W. Jonsson et al. (1995) 
had also described three patients with this mutation, all presenting a mild phenotype. In contrast, Froissart et al. (2007) themselves, besides other authors (Isogai et al., 1998; Lin et al., 2006), reported severe phenotypes associated to this mutation in different patients. On the other hand, Li et al. (1999) did not report the phenotypic classification of their patients, due to lack of clinical data.

The polymorphisms p.V358M and p.V376M were detected in patients $\mathrm{P} 8$ and $\mathrm{P} 9$, respectively, both presenting a severe phenotype. These polymorphisms are also produced by transitions at $\mathrm{CpG}$ nucleotides and, when associated with some disease-causing mutations, can contribute for a decrease in enzymatic activity, thus influencing the clinical development of the patients (Karageorgos et al., 2004).

Petry et al., (2005) established a correlation between the presence of polymorphisms p.V358M and p.V376M in MPS VI patients with a severe to intermediate phenotype. Although their patients presented the same polymorphisms and phenotypes, their mutations were variable. This suggests that the presence of $\mathrm{p} . \mathrm{V} 358 \mathrm{M}$ and p.V376M is not necessarily linked to a specific mutation, but patients with these polymorphisms can present similar phenotypes.

Our study demonstrated that ERT was capable of significantly reducing urinary GAG excretion in all MPS patients undergoing this treatment. Although some data regarding the clinical evaluations were not available, this reduction, according to the literature (Harmatz et al., 2005, 2008; Arora et al., 2007; Sifuentes et al., 2007), is strictly related to the improvement of the patients' clinical picture.

We observed a significant reduction $(p<0.01)$ in urinary GAG excretion in MPS I and MPS VI patients. In MPS I, the overall reduction was of about $94 \%$ for patient P1, and $41 \%$ for patient P2. In MPS VI patients, the overall reduction was of about $77 \%$ for patient $\mathrm{P} 7$ and $73 \%$ for patient P8. Similar total reduction rates were also reported in the literature, where reduction levels of $54 \%$ to $60 \%$ during the initial weeks, $59 \%$ during treatment, and between $69 \%$ and $88 \%$ after six years were described (Wraith et al., 2004, 2007; Sifuentes et al., 2007). Furthermore, higher enzyme doses have been reported to be more efficient than lower doses in achieving clinical improvements and reduction of urinary GAG in MPS patients undergoing ERT (Harmatz et al., 2005, 2008).

This is the first genetic and biochemical report on MPS patients from northern Brazil. The mutations and polymorphisms identified in these MPS patients were all previously reported in Brazilian patients. Urinary GAG excretion was significantly reduced in all MPS patients undergoing ERT, confirming the responsiveness of this treatment. A complete molecular screening and a comprehensive epidemiological investigation of all patients, performed at health care centers near to their birth places, could contribute to earlier diagnosis and treatment, as well as to a better understanding of the etiology of the disease.

\section{Acknowledgments}

We would like to thank the Hospital Universitário Bettina de Ferro Souza (HUBFS/UFPA), the Instituto de Genética Médica Populacional (INAGEMP) and the MPS Brazil Network for their important collaboration. We also would like to thank Fundação de Amparo à Pesquisa do Estado do Pará (FAPESPA) and Conselho Nacional de Desenvolvimento Científico e Tecnológico (CNPq; grant number \#573993/2008-4) for the financial support provided.

\section{References}

Alves S, Mangas M, Prata MJ, Ribeiro G, Lopes L, Ribeiro H, Pinto-Basto J, Lima MR and Lacerda L (2006) Molecular characterization of Portuguese patients with mucopolysaccharidosis type II shows evidence that the IDS gene is prone to splicing mutations. J Inherit Metab Dis 29:743-754.

Arora RS, Mercer J, Thornley M, Tylee K and Wraith JE (2007) Enzyme replacement therapy in 12 patients with MPS I-H/S with homozygous p.Leu490Pro mutation. J Inherit Metab Dis $30: 821$.

Castro N, Bentes E, Souza I, Giugliani R and Santana-da-Silva L (2007) Estimativa do perfil epidemiológico de Mucopolissacaridoses no Estado do Pará. Pediatria Moderna 43:2328.

El Dib RP and Pastores GM (2007) Laronidase for treating mucopolysaccharidosis type I. Genet Mol Res 6:667-674.

Froissart R, Da Silva IM and Maire I (2007) Mucopolysaccharidosis type II: An update on mutation spectrum. Acta Paediatr Supp 96:71-77.

Gatti R, DiNatale P, Villani GR, Filocamo M, Muller V, Guo XH, Nelson PV, Scott HS and Hopwood JJ (1997) Mutations among Italian mucopolysaccharidosis type I patients. J Inherit Metab Dis 20:803-806.

Harmatz P, Ketteridge D, Giugliani R, Guffon N, Teles EL, Miranda MC, Yu ZF, Swiedler SJ and Hopwood JJ (2005) Direct comparison of measures of endurance, mobility, and joint function during enzyme-replacement therapy of mucopolysaccharidosis VI (Maroteaux-Lamy syndrome): Results after 48 weeks in a phase 2 open-label clinical study of recombinant human N-acetylgalactosamine 4-sulfatase. Pediatrics 115:e681-e689.

Harmatz P, Giugliani R, Schwartz IV, Guffon N, Teles EL, Miranda MC, Wraith JE, Beck M, Arash L, Scarpa M, et al. (2008) Long-term follow-up of endurance and safety outcomes during enzyme replacement therapy for mucopolysaccharidosis VI: Final results of three clinical studies of recombinant human $\mathrm{N}$-acetylgalactosamine 4-sulfatase. Mol Genet Metab 94:469-475.

Isogai K, Sukegawa K, Tomatsu S, Fukao T, Song XQ, Yamada Y, Fukuda S, Orii T and Kondo N (1998) Mutation analysis in the iduronate-2-sulphatase gene in 43 Japanese patients with mucopolysaccharidosis type II (Hunter disease). J Inherit Metab Dis 21:60-70.

Jonsson JJ, Aronovich EL, Braun SE and Whitley CB (1995) Molecular diagnosis of mucopolysaccharidosis type II (Hunter syndrome) by automated sequencing and computer-assisted interpretation: Toward mutation mapping of the iduronate2-sulfatase gene. Am J Hum Genet 56:597-607. 
Karageorgos L, Harmatz P, Simon J, Pollard A, Clements PR, Brooks DA and Hopwood JJ (2004) Mutational analysis of mucopolysaccharidosis type VI patients undergoing a trial of enzyme replacement therapy. Hum Mutat 23:229-233.

Li P, Bellows AB and Thompson JN (1999) Molecular basis of iduronate-2-sulphatase gene mutations in patients with mucopolysaccharidosis type II (Hunter syndrome). J Med Genet 36:21-27.

Lin SP, Chang JH, Lee-Chen GJ, Lin DS, Lin HY and Chuang CK (2006) Detection of Hunter syndrome (mucopolysaccharidosis type II) in Taiwanese: Biochemical and linkage studies of the iduronate-2-sulfatase gene defects in MPS II patients and carriers. Clin Chim Acta 369:29-34.

Mangas M, Nogueira C, Prata MJ, Lacerda L, Coll MJ, Soares G, Ribeiro G, Amaral O, Ferreira C, Alves C, et al. (2008) Molecular analysis of mucopolysaccharidosis type IIIB in Portugal: Evidence of a single origin for a common mutation (R234C) in the Iberian Peninsula. Clin Genet 73:251-256.

Matte U, Leistner S, Lima L, Schwartz I and Giugliani R (2000) Unique frequency of known mutations in Brazilian MPS I patients. Am J Med Genet 90:108-109.

Matte U, Yogalingam G, Brooks D, Leistner S, Schwartz I, Lima L, Norato DY, Brum JM, Beesley C, Winchester B, et al. (2003) Identification and characterization of 13 new mutations in mucopolysaccharidosis type I patients. Mol Genet Metab 78:37-43.

Meikle PJ, Hopwood JJ, Clague AE and Carey WF (1999) Prevalence of lysosomal storage disorders. JAMA 281:249-254.

Miebach E (2005) Enzyme replacement therapy in mucopolysaccharidosis type I. Acta Paediatr Suppl 94:58-60, discussion 57.

Muenzer J (2004) The mucopolysaccharidoses: A heterogeneous group of disorders with variable pediatric presentations. J Pediatr 144:S27-34.

Muenzer J, Wraith JE and Clarke LA (2009) Mucopolysaccharidosis I: Management and treatment guidelines. Pediatrics 123:19-29.

Neufeld EF and Muenzer J (2001) The mucopolysaccharidoses. In: Scriver CR, Beaudet AL, Sly WS and Valle D (eds) The Metabolic and Molecular Bases of Inherited Disease. McGraw-Hill, New York, pp 3421-3452.

Petry MF, Nonemacher K, Sebben JC, Schwartz IV, Azevedo AC, Burin MG, de Rezende AR, Kim CA, Giugliani R and Leistner-Segal S (2005) Mucopolysaccharidosis type VI: Identification of novel mutations on the arylsulphatase B gene in South American patients. J Inherit Metab Dis 28:1027-1034.

Pitz S, Ogun O, Arash L, Miebach E and Beck M (2009) Does enzyme replacement therapy influence the ocular changes in type VI mucopolysaccharidosis? Graefes Arch Clin Exp Ophthalmol 247:975-980.

Sambrook J and Russel DW (2001) Molecular Cloning - A Laboratory Manual. 3rd edition. Cold Spring Harbor Laboratory Press, New York.

Sifuentes M, Doroshow R, Hoft R, Mason G, Walot I, Diament M, Okazaki S, Huff K, Cox GF, Swiedler SJ, et al. (2007) A follow-up study of MPS I patients treated with laronidase enzyme replacement therapy for 6 years. Mol Genet Metab 90:171-180.

Solyom E (1996) Incidence data for Mucopolysaccharidoses in Hungary. 4th International Symposium on Mucopolysaccharide and Related Diseases Program, Wollongong, Australia, pp 75.

Venturi N, Rovelli A, Parini R, Menni F, Brambillasca F, Bertagnolio F, Uziel G, Gatti R, Filocamo M, Donati MA, et al. (2002) Molecular analysis of 30 mucopolysaccharidosis type I patients: Evaluation of the mutational spectrum in Italian population and identification of 13 novel mutations. Hum Mutat 20:231.

Whitley CB, Ridnour MD, Draper KA, Dutton CM and Neglia JP (1989) Diagnostic test for mucopolysaccharidosis. I. Direct method for quantifying excessive urinary glycosaminoglycan excretion. Clin Chem 35:374-379.

Wraith JE, Clarke LA, Beck M, Kolodny EH, Pastores GM, Muenzer J, Rapoport DM, Berger KI, Swiedler SJ, Kakkis $\mathrm{ED}$, et al. (2004) Enzyme replacement therapy for mucopolysaccharidosis I: A randomized, double-blinded, placebo-controlled, multinational study of recombinant human alpha-L-iduronidase (laronidase). J Pediatr 144:581-588.

Wraith JE, Beck M, Lane R, van der Ploeg A, Shapiro E, Xue Y, Kakkis ED and Guffon N (2007) Enzyme replacement therapy in patients who have mucopolysaccharidosis I and are younger than 5 years: Results of a multinational study of recombinant human alpha-L-iduronidase (laronidase). Pediatrics 120:e37-46.

Associate Editor: Paulo A. Otto

License information: This is an open-access article distributed under the terms of the Creative Commons Attribution License, which permits unrestricted use, distribution, and reproduction in any medium, provided the original work is properly cited. 